\title{
靴着用時における歩行中の足甲接触圧の経時変化 ${ }^{1}$
}

\author{
武末 慎 ${ }^{2}$, LOH Ping Yeap ${ }^{3}$, 村木里志 ${ }^{3}$ ，濱中伸介 ${ }^{4}$, \\ 山田敦志 ${ }^{4}$, 池上功一 ${ }^{4}$, 和田健希 ${ }^{4}$, 古達浩史 ${ }^{4}$
}

\begin{abstract}
The main objective of this study was to identify the distribution of contact pressure on the dorsal surface of the foot during walking in shoes. Ten healthy young men (age, $22.1 \pm 0.6$ years) without any walking impediments were recruited in this study. Foot measurement was performed to identify the appropriate shoe size for each participant prior to the experiment. Subsequently, FlexiForce sensors were attached to (1) the dorsal side of the first metatarsophalangeal joint, (2) the most medial side of the first interphalangeal joint, (3) the metatarsal fibulare, (4) the dorsal side of the fifth metatarsophalangeal joint, (5) the intermediate cuneiform, and (6) the pternion to measure the contact pressure during walking. In addition, foot switch sensors were used to identify the gait cycle as participants walked on the designated walkway. The contact pressure at points (1) and (6) showed distinctive increments at both heel contact and toe off. On the contrary, points (2), (3), and (4) showed decrements at the swing phase. The observed distribution of the contact pressure on the dorsal foot may be caused by the shape changes of the shoes and the foot joint movement during walking.
\end{abstract}

本研究は，靴着用時における歩行中の足甲接触圧分布の特徵を明らかにすることを目的とした．被験者は 若年者男性10名であった．足部皮膚上の母趾球上面，第一趾脛側最突出点，腓側中足点，小趾球上面，第二 楔状骨点および踵点に薄型圧力センサを貼り付けた状態で足部寸法計測により選定したサイズの測定靴を着 用させた．約 $10 \mathrm{~m}$ の木板歩行路上を自由歩行の速度で歩行を行い，歩行動作中の足甲接触圧を測定した．母 趾球上面および踵点における足甲接触圧の経時変化は踵接地時扔よび足部踣り出し時において静止立位時の 接触圧と比較して有意に高值を示していた．また，第一趾脛側最突出点，腓側中足点および小趾球上面では 遊脚期中の接触圧が静止立位時に比べ有意に低かった．荷重の受け継ぎや身体の前進に特に重要な役割を果 たしている歩行相では接触圧が増加する部位が多く見られ，足部が地面から離れている遊脚期では靴設計時 の隙間により接触圧が低くなる部位があった，以上のように，足と靴の歩行中の足甲接触圧の特徵を明らか にすることができた.

(キーワード : 歩行, 靴，フィット性，接触圧，アッパー）

\section{1.はじめに}

我々は，屋外で活動するときに靴を履く，靴は外的環 境によるさまざまな刺激から足を保護し，歩行などの移 動動作を円滑にする役割を持つ1,2). 西脇は靴に必要な設 計条件機能として, クッション性・軽量性・耐久性・安 定性・グリップ性・屈曲性・フィット性・通気性の8つを

1 受付：2017年11月16日 受理：2018年4月5日

2 九州大学大学院芸術工学府

Graduate School of Design, Kyushu University

3 九州大学大学院芸術工学研究院

Faculty of Design, Kyushu University

4 株ムーンスター

MoonStar Company
挙げ，中でもフィット性はアッパーの材料や構造に依存 することから，あらゆる靴に対して特に重要な機能であ る3 5) と述べている. また実際に使用者が靴を購入する際， 最も重要視する機能はフィット性である ${ }^{6)}$ という報告も ある．以上のことから，設計上の要素においても，使用 者の視点に抢いても足と靴のフィット性の重要度は高い といえる。

このフィット性は，個人により異なる評価基準があ り，使用者の要求が多岐にわたる4)。一般的に，静止立 位時においては靴製作時の足型となる靴のラスト形状と 足部形状の差が小さければ靴の足への追従性が高くなり フィット感が向上する7)。旮故，フィット性を向上させ る靴を作製するためにはラスト形状の設計が重要となる. 他方，静止立位時におけりる足甲接触圧分布がフィット性 
と関連があることが報告されている，高島らは，静止立 位時において着用する靴の違いにより足甲接触圧に变化 が生じ，着用者の感じるフィット感に差異を及ぼす8)こ とを明らかにした，このことは，足甲接触圧はフィット 性を定量的に評価できる指標であることを示唆してい る。しかしながら，足部の形状はその足部の運動により 変化する ${ }^{9,10)}$. このため, 静止立位時の足部形状に加え て，動作時，例えば靴を着用している時に最も多く行わ れる歩行の動作中に発生する足部形状の変化にも対応す るアッパー構造を設計する必要がある。

靴の変形などを考慮に入れた足と靴のフィット性の評 価を試みた先行研究には，野川らが定義した「嗜好を含 んだフィット感」を示す評価指標と多くの足の物理量と 相関が見られたという報告11)や，靴のひずみを測定して アッパーの足への追従性を評価した報告) がある. しか しこれらの研究は，主観的な評価や靴の特徵的な形状変 化時におけるフィット性の検討にとどまっており，歩行 動作中の経時的に形状変化する足と靴のフィット性を捉 えるまでには至っていない.Jordanらは歩行中の足甲部 における圧力のピーク值が靴のアッパーでの快適性に関 連がある12)ことを示した。 さらに歩行中の足甲部に打け る接触圧測定をアニメーションへ活用した研究として, 圧力センサを用いて歩行中の足甲接触圧を測定し，靴の 動態の仮想シミュレーションを行った報告 ${ }^{13)}$ がある。こ れらの先行研究により，足甲接触圧が歩行時の足と靴の 関係性を表す一要素であり, 歩行動作中のフィット性を 定量的に評価できる可能性が示された。

前述のように，歩行中に打ける足長などの足部形状の 変化の影響により, 静止立位時にフィットしている靴で あっても歩行中にフィットしているとは限らない，歩行 中のフィット性を検討するためには，経時的な足と靴の 動態を定量的に明らかにし，両者の動的関係性を理解す る必要がある。しかしながら, 歩行中の足甲接触圧を測 定し歩行動作との関連を検討した研究はみられない。靴 着用時に打ける歩行中の足甲接触圧の経時変化を立位静 止時と比較することにより, 歩行中のどのタイミングに おいて足と靴のアッパー部が接触するのかといった，歩 行中における足と靴の接触の特徵を理解することができ る.さらに靴の開発に打いてフィット性の向上を目指し た設計要件の検討への応用が期待される.

そこで本研究では，足部に貼付した状態で靴を着用し た際でも，足部への圧迫が小さく歩行動作への影響が少 ない薄型圧力七ンサを用いて, 靴着用時に打ける歩行中 の足甲接触圧分布の経時的な特徵を明らかにすることを 目的とした。なお，本研究では老若男女を問わず利用率
が高いウォーキングシューズを対象とした。 ウォーキン グシューズは他の種類の靴よりもフィット性がより重視 された設計になっている．ウォーキングシューズで認め られる接触圧の増加は他の靴でも同様に認められる可能 性が高く，知見の汎用性にとっても望ましいと考えた。

\section{2. 方 法}

\section{2-1. 被験者}

被験者は健康で歩行に支障をきたす既往のない若年 者男性10名とした。 あらかじめChapmanらの利き足テス 卜14)を用い，被験者全員の利き足が右脚であることを確 認した。倫理的配慮として，被験者には実験の趣旨，研 究参加に際して保障される権利等について文書打よび口 頭で説明し，実験参加への同意を得た。なお，本研究は 九州大学大学院芸術工学研究院実験倫理委員会の承認 （承認番号56）を得ている.

\section{2-2. 実験手順}

実験は10 mの直線歩行路が確保できる実験室内にて実 施した．実験室の床面上には幅 $0.4 \mathrm{~m}$ ，全長 $10 \mathrm{~m}$ の水平な 木板歩行路を配置した。被験者には，測定靴（2-3.参照） を着用させ， $10 \mathrm{~m}$ の距離を歩行する課題を行わせた．歩 行中はまっすぐ前を見て歩くように指示した．歩行速度 条件は自由歩行とし，被験者が普段通りに歩く速度とし た. 歩行課題前に被験者へ「いつもどおりの速さでまっ すぐ前を向いて歩いてください」と教示した.

実験はまず被験者の身体計測および足部寸法計測を

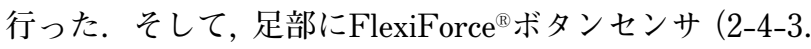
参照）を貼り付けた状態で，靴下によるクッション性や 着圧の影響を排除するために被験者には靴下を着用させ ずに，足部寸法計測の結果よりサイズを決定した測定靴 を着用させた。靴内部で足が動かないように，被験者が 履きやすいと感じる程度の締めつけ具合で靴紐を用いて 固定させた．次に，被験者には実験環境や測定靴に慣れ， 普段通りの歩行ができるようになるまで歩行路上を繰り 返し往復する歩行練習を 5 ～10分程度行わせた。 その後, 5分程度の休鄎を取り，歩行課題を行わせた．歩行動作 の測定は5回繰り返し行った。また，歩行動作の前後に それぞれ5秒間の静止立位時における足甲接触圧を測定 した。この時，足を肩幅程度に開き足部の踵と第二趾を 結ぶ線が矢状面に対し平行になるように指示した。

原著: 靴着用時に打ける歩行中の足甲接触圧の経時変化 


\section{2-3. 靴条件}

靴の素材や形状の影響を排除するため, 統一した測定 靴を使用した。測定靴には，(株)ムーンスター製のウォー キングシューズ (WM3087, ウィズ4E，表記サイズ $26.0 \mathrm{~cm}$ における片足重量 $360 \mathrm{~g}$, 紐靴タイプ, 困1）を使 用した。

\section{2-4. 測定項目}

\section{2-4-1. 足部寸法計測}

足部寸法の計測はすべて右足で行った．足部寸法計測 により，(1)足長 $[\mathrm{cm}]$, (2)足幅 $[\mathrm{cm}]$, (3)足囲 $[\mathrm{cm}]$, (4) インステップ囲 $[\mathrm{cm}]$, (5)足高 $[\mathrm{cm}]$, (6)第一趾高 $[\mathrm{cm}]$, (7)外果端高 $[\mathrm{cm}]$, (8)第一趾側角度 $[\mathrm{deg}]$ および9)第五 趾側角度 $[\mathrm{deg}$ ）を計測・算出した（図2). 足長打よび 足幅は，桿状計を用いて計測した。足囲およびインス テップ囲は巻尺を用いて計測した．足高，第一趾高およ び外果端高はアントロポメータを用いて計測した。第一 趾および第五趾側角度は，脛側および腓側中足点を通り 足底縦軸線と平行な直線と脛側および腓側中足点と第一

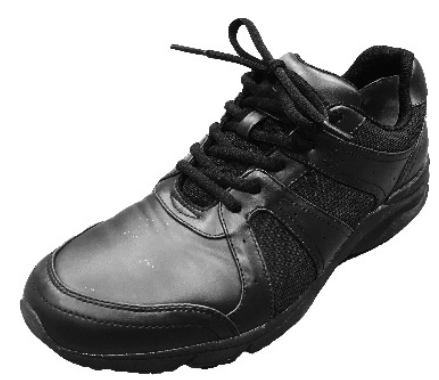

図1 測定靴

Fig. 1 Experimental shoes.
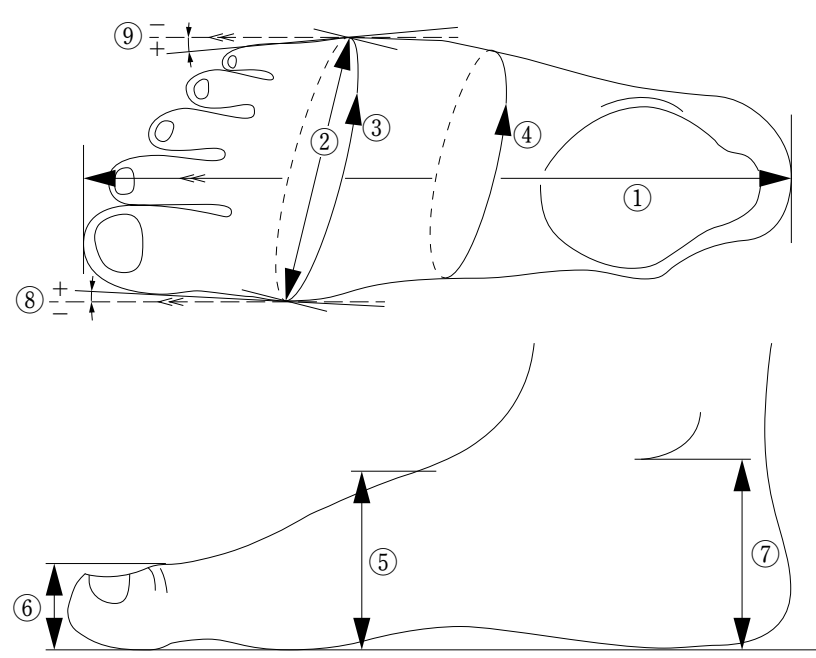

図2 足部寸法計測

Fig. 2 Measurement contents of the foot part.
趾脛側および第五趾腓側最突出点を結ぶ直線がなす角度 を求めた．このとき，脛側および腓側中足点と第一趾脛 側，第五趾腓側最突出点を結ぶ直線が足底縦軸線に対す る平行線よりも足部中央側にくる場合の角度を正の值と した。計測で得た足長，足幅および足囲の結果からJIS S 5037-1998「靴のサイズ」15)の付表を用い，各被験者の 靴の適正サイズを確認した。

\section{2-4-2. 歩行指標}

歩行周期を算出するために，測定靴の底面（踵部，前 足部) に貼付したフットスイッチ (DKH社製，荷重スイッ チPH-463，センサ直径 $12 \mathrm{~mm}$ ) を用いて，踵接地および つま先離地のタイミングを検出した. フットスイッチか らの信号は，4ch FSアンプ（DKH社製，PH-450）を介 し，端子台（CONTEC社製，ATP-32F)，シールドケー ブル $(\mathrm{CONTEC}$ 社製，ADC-68M/96F)，アナログ入出 カカード (CONTEC社製，ADA16-32/2（CB）F）を接 続した収録ソフトウェアVitalRecorder2（キッセイコム

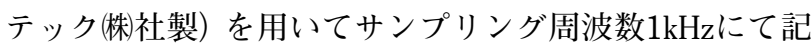
録した。一歩行周期は右脚踵接地を $0 \%$ ，次の右脚踵接 地を $100 \%$ とし，正規化した（以下，一歩行周期をGC： Gait Cycle)。これにより，歩行周期 [s］，歩調［steps/ $\mathrm{min}]$ ，遊脚期，立脚期および両脚支持期が一歩行周期中 に占める割合 $[\%]$ を計測・算出した． 5 試行分の測定 值の平均值を算出した。歩行周期は一歩行周期に要する 時間，歩調は単位時間内の歩数である.

\section{2-4-3. 接触圧}

厚さ $0.2 \mathrm{~mm}$ と薄く，足部に貼付した状態で靴を着用 した時に大きな圧迫がなく歩行動作への影響が少ない FlexiForce $^{\circledR}$ ボタンセンサ (Tekscan社，A201-1，以下，FF センサ，図3）を用いて，歩行動作中の足甲接触圧を計測

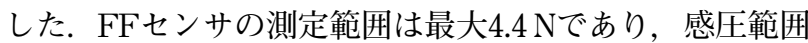
はセンサ先端部の直径 $9.5 \mathrm{~mm}$ の円形である. FFセンサか
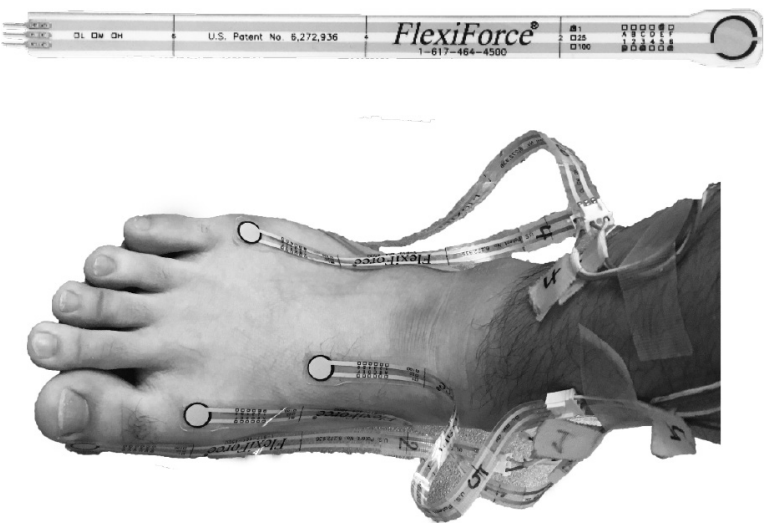

図3 FlexiForce ${ }^{\circledR}$ ボタンセンサの貼付例

Fig. 3 Placement of a FlexiForce sensor. 
らの信号は，amp boxシリーズ (ニッタ(株社製) の1つのマ

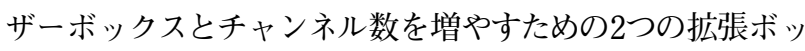
クスを介し，前節のフットスイッチの信号と同様の端子台， シールドケーブル，アナログ入出力カードを接続した収録 ソフトウェアVitalRecorder2を用いてサンプリング周波数 $1 \mathrm{kHz}$ にて記録し，歩行指標のデータと同期させた.

FFセンサには直線性があるが，センサによりそれぞ れ特性が異なるため，使用したセンサに対してそれぞれ キャリブレーションを行った. キャリブレーションには， 重さが既知の錘を用い，FFセンサの感圧部にのみ荷重 がかかるように円形に切り出した木片を載せ，その上に， 50〜 $550 \mathrm{~g}$ まで11種類の重さが異なる鏵を負荷した時の 電圧值に，無荷重時の電圧值を加えた 12 項目に対する電 圧值の平均值を用いて線形回帰を行った。

記録したFFセンサ信号の導出には，解析ソフトウェ アKineAnalyzer（キッセイコムテック(株社製）を用いた. それぞれの結果に $10 \mathrm{~Hz}$ のローパスフィルタを適応して あらかじめノイズを除去した後に，歩行周期により正規 化を行い，一歩行周期 5 試行分のデータを平均化し，そ れらの值を接触圧の経時変化の代表值とした.

$\mathrm{FF} ン サ の$ 貼り付け部位は，(1)母趾球上面，(2)第一 趾脛側最突出点，(3)腓側中足点，(4)小趾球上面，(5)第二 楔状骨点および6踵点とし，足甲接触圧 $[\mathrm{kPa}]$ の経時 変化を計測・算出した。足甲接触圧の測定部位は触診に より選定したＦFセンサの貼付例を図3に，足甲接触圧 の測定部位を図4に示す.

\section{2-5. 統計処理}

各部位における接触圧の経時変化については，一歩行 周期を $5 \% \mathrm{GC}$ ごとの間へと分類した. 0 〜 $\% \mathrm{GC} ， 5$ $10 \% \mathrm{GC} ， \cdots ， 95 \sim 100 \% \mathrm{GC}$ のうに合計20区間におけ る接触圧の平均值を各区間の代表值とした。歩行動作中 の接触圧の変化を検討するために, 各歩行動作タイミン グの接触圧の代表值および静止立位時の接触圧の比較を

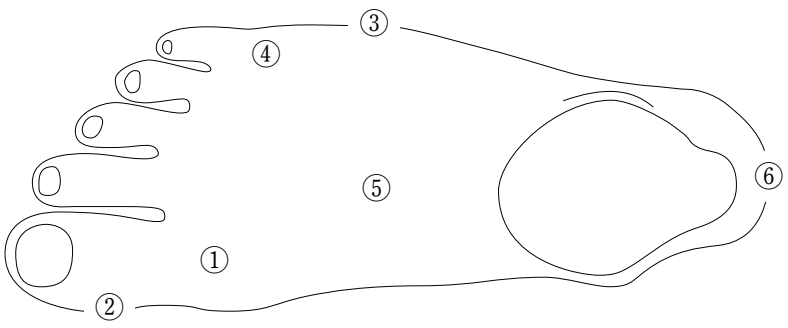

(1)母趾球上面，(2)第一趾脛側最突出点，(3)腓側中足点, (4)小趾球上面，5)第二楔状骨点，6)踵点

図4 足甲接触圧の測定部位

Fig. 4 Landmarks for the contact pressure sensors.
行つた.

すべての接触圧の結果に対して正規性が認められたた め対応のある $t$ 検定を用い，各歩行周期中の接触圧と静 止立位時の接触圧の比較を行った。すべての統計解析に はSPSS Statistics Version 21 for Windows（IBM）を用い, 有意水準を $5 \%$ 未満とした.

\section{3. 結 果}

\section{3-1. 身体特性および足部寸法計測}

被験者の身体特性および足部寸法計測の平均值と標準 偏差を表1に示す。足長，足幅および足囲の結果から決 定した使用する測定靴のサイズとその人数は，25.5 cmが 4 名， $26.0 \mathrm{~cm}$ が名， $26.5 \mathrm{~cm}$ が名であった。

\section{3-2. 歩行指標}

歩行指標の平均值および標準偏差の值を表 2 に示す. 歩調打よび立脚期割合は，成人男性の標準的な歩調 $\left(111 \mathrm{steps} / \mathrm{min}^{16)}\right)$ ，一般的な立脚期割合 $\left(60 \%{ }^{17)}\right)$ およ

表1 被験者の身体特性および足部寸法

Tab. 1 Physical and anthropometric characteristics of the participants.

\begin{tabular}{lcc}
\hline & 平均値 & 標準偏差 \\
\hline 年齢 $[$ 歳 $]$ & 22.1 & 0.6 \\
身長 $[\mathrm{cm}]$ & 174.2 & 4.7 \\
体重 $[\mathrm{kg}]$ & 66.6 & 8.8 \\
BMI $\left[\mathrm{kg} / \mathrm{m}^{2}\right]$ & 22.0 & 3.0 \\
大転子高 $[\mathrm{cm}]$ & 86.8 & 3.8 \\
足長 $[\mathrm{cm}]$ & 25.6 & 0.5 \\
足幅 $[\mathrm{cm}]$ & 10.4 & 0.3 \\
足囲 $[\mathrm{cm}]$ & 24.7 & 0.7 \\
インステップ囲 $[\mathrm{cm}]$ & 24.6 & 0.8 \\
足高 $[\mathrm{cm}]$ & 6.1 & 0.5 \\
第一趾高 $[\mathrm{cm}]$ & 2.0 & 0.3 \\
外果端高 $[\mathrm{cm}]$ & 6.7 & 0.4 \\
第一趾側角度 $[\mathrm{deg}]$ & -0.2 & 5.3 \\
第五趾側角度 $[\mathrm{deg}]$ & 4.4 & 3.9 \\
\hline
\end{tabular}

表2 歩行指標の結果

Tab. 2 Gait cycle index results.

\begin{tabular}{lcc}
\hline & 平均值 & 標準偏差 \\
\hline 歩行周期 $[\mathrm{s}]$ & 1.2 & 0.1 \\
歩調 $[\mathrm{steps} / \mathrm{min}]$ & 102.5 & 8.2 \\
立脚期割合 $[\%]$ & 58.1 & 1.8 \\
遊脚期割合 $[\%]$ & 41.9 & 1.8 \\
両脚支持期割合 [\%] & 7.6 & 2.0 \\
\hline
\end{tabular}



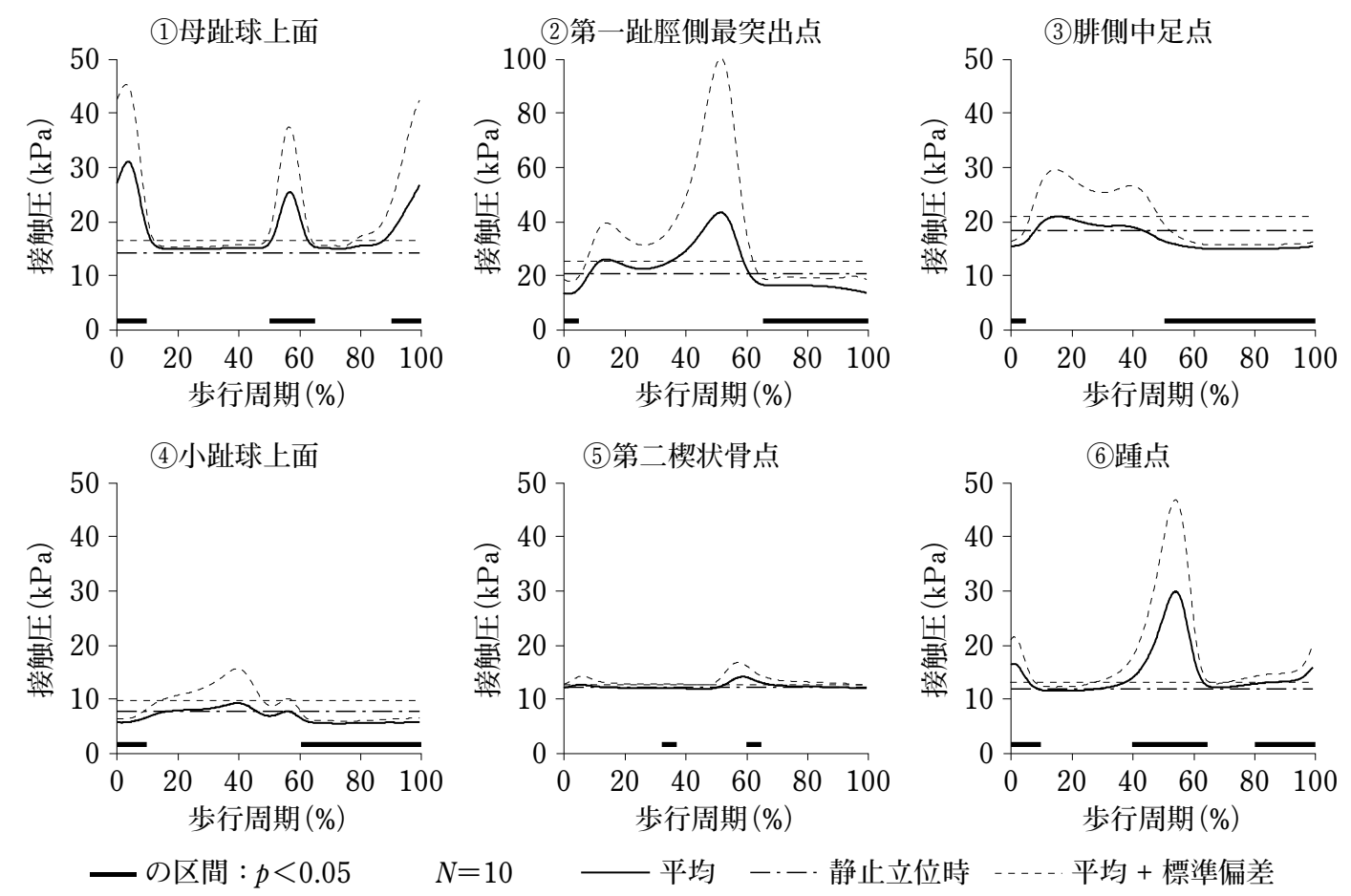

図5 接触圧の経時変化

Fig. 5 Distribution of contact pressure.

び両脚支持期割合 $\left(10 \%{ }^{17)}\right)$ よりも低い值を示した。

\section{3-3. 接触圧}

(1)母趾球上面，(2)第一趾脛側最突出点，(3)腓側中足点， (4)小趾球上面，(5)第二楔状骨点および6)踵点における接 触圧の経時変化の平均值（実線）とその標準偏差（破線） および静止立位時における接触圧の平均值（一点鎖線） を図5に示す，各測定部位に対して歩行動作中の各区間 における接触圧と静止立位時の接触圧を比較し, 有意差 が認められた区間を，罒中下部に黒太線で示した.

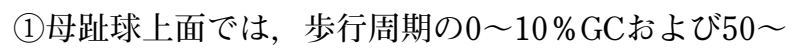
$65 \% \mathrm{GC} ， 90 \sim 100 \% \mathrm{GC}$ にいて静止立位時に比べ有意 に接触圧の増加が見られた。 また歩行周期中は静止立位 時に比べ，常に高い接触圧を示した。 (2)第一趾脛側最突

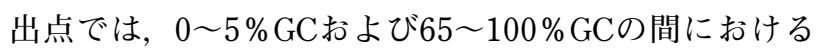
接触圧が静止立位時の接触圧に比べて有意に低い值を示 した. (3)腓側中足点では，0〜 5\% GCおよび50〜100\% GCの間における接触圧が静止立位時の接触圧に比べて 有意に低い值を示した. (4)小趾球上面では，0〜10\% GC および60〜 $100 \%$ GCの間における接触圧が静止立位時の 接触圧に比べて有意に低い值を示した. (5)第二楔状骨点 においては，30〜 35\% GC間の接触圧が静止立位時の接 触圧に比べて有意に低い值を示した．また， 60～65\% GCのタイミングにおける接触圧が静止立位時の接触圧 に比べて有意に高い值を示した。（6踵点においては，0
〜 10\%GCおよび40〜 $65 \% \mathrm{GC｝ \text {80〜100\%GCの間におけ }}$ る接触圧が静止立位時の接触圧に比べて有意に高い值を 示した.

以上のことから，(1)母趾球上面および(6)踵点において 歩行周期中の踵が接地する期間（0〜 $10 \% \mathrm{GC})$ ，足部蹴 り出しのタイミング $(50 \sim 60 \% \mathrm{GC})$ および遊脚後期 $(80$ 〜 $100 \% \mathrm{GC})$ の期間で接触圧の増加が見られたことが分 かる. また，(2)第一趾脛側最突出点，(3)腓側中足点およ び(4)小趾球上面においては，踵接地（0１0\% GC）およ び遊脚期（60〜 $100 \% \mathrm{GC} ）$ の期間で静止立位時に比べ接 触圧が低下していることが分かった.

\section{4. 考 察}

0〜10\%GCの期間では，(1)母趾球上面および6)踵点に おいて有意な接触圧の増加が見られた。一方で，(2)第一 趾脛側最突出点, (3)腓側中足点および(4)小趾球上面で は静止立位時の接触圧に比べ有意に低下していた，0〜 $10 \% \mathrm{GC}$ は歩行周期の中で身体重量が前方の下肢に移さ れるタイミングである。この期間において，足部と靴で は異なる回転運動を行うことが考えられる．足部接地の 機序として，まず踵点の後方縁が接地し，その後急速に 前方回転して踵の中心が接地する18,19).この時, 踵がロッ カーの役目を果たすことで身体のなめらかな前進が可能 となり，足部では，前脛骨筋および長趾伸筋の強力な遠 
心性筋収縮により体重べクトルに対する背屈モーメント が発生する ${ }^{17)}$ ， そのため，足関節の底屈運動は抑制され ると考えられている。一方, 靴にはこの背屈方向へのモ一 メントが発生しないため底屈方向へ制御されない回転運 動を行おうとする。これにより，0〜10\%GCの期間にお ける足関節の底屈方向への回転運動と靴の回転運動との 間に差が生じ，母趾球上面において接触圧が増加したと 示唆される。また，この期間中に足部は内返しの運動を 行う。しかしながら靴はこの足部の運動に対応できなかっ たために(1)母趾球上面で接触圧が増加したのに対して(4) 小趾球上面においては，接触圧が低下したのではないか と考えられる.

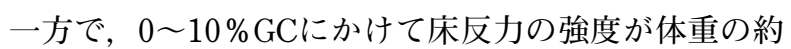
50〜 $125 \%$ に及ぶ20) ため，踵点ではこの期間において接 触圧が静止立位時に比べて大きく増加すると予想された。 しかし，実際は足部接地の期間における踵点での接触圧 は静止立位時に比べ有意に増加はしているが，蹴り出し の期間における接触圧の増加と比較して大きな接触圧の 增加は見られなかった．これは，初期接地において支持 面が踵しかない状態で急速に体重が前方の下肢に移動す ることによって生じる一過性現象 ${ }^{211}$ ，打よびヒールロッ カー機能17)による踵点を支点とした回転が瞬時に行われ たために，踵部への接触圧増加の軽减が生じたためでは ないかと推測される．同時に，運動靴では靴の変形によ り靴が接地するソール部分での踵部において運動エネル ギーが吸収される22) ため，足部にかかる荷重が靴によっ て踵点だけでなく足部全体に分散されたのではないかと 考えられる．また，0〜 $10 \% \mathrm{GC}$ 期間には踵部で足部接 地を行うため前足部には荷重がかからない。これにより 足部寸法が小さくなり，(2)第一趾脛側最突出点および(3) 腓側中足点では接触圧が低下したと考えることができる.

50〜 65\% GCの期間では(1)母趾球上面，(5)第二楔状骨 点およびの踵点に打いて接触圧の有意な増加が見られた。 この期間はしばしば蹴り出しとも呼ばれ，足趾はまだ床 に接しているが, 荷重が反対脚へと受け継がれることで, 身体の前進に大きく貢献する役割を果たしている ${ }^{16,17)}$. このとき足部では中足趾節関節の背屈に伴い，靴が屈曲 しアッパー構造が変形し湾曲したために靴の構造が変化 し，(1)母趾球上面を圧迫することで，接触圧が増加した と考えられる。また，足部蹴り出しの期間において足関 節は底屈し膝関節は屈曲することで足部は前進しょうと する. しかし，踵の挙上により足中足趾節関節の背屈に 伴い屈曲した靴のソール部には弾性力が働き元の形に戻 ろうとする。 そのため，足部打よび靴はそれぞれ反対方 向に運動を行うことで(5)第二楔状骨点および(6)踵点の接 表3＼cjkstart靴の適正サイズおよびウィズ

Tab. 3 Appropriate shoe size and width for each participant.

\begin{tabular}{ccccc}
\hline 人数 $(N=10)$ & \multicolumn{5}{c}{ ウイズ } \\
\cline { 2 - 5 } サイズ $[\mathrm{cm}]$ & $\mathrm{E}$ & $2 \mathrm{E}$ & $3 \mathrm{E}$ & $4 \mathrm{E}$ \\
\hline 25.5 & 2 & 1 & 0 & 1 \\
26.0 & 1 & 1 & 1 & 0 \\
26.5 & 1 & 2 & 0 & 0 \\
\hline
\end{tabular}

触圧が増加したと推察できる。

遊脚期中では(2)第一趾脛側最突出点，(3)腓側中足点お よび(4)小趾球上面に打いて静止立位時の接触圧に比べて 有意に低い值を示した。これは，遊脚期は足部が持ち上 げられ空中にある期間であるため，足部への荷重が静止 立位時よりも小さくなる．このため，足部寸法が小さく なることで, 靴の設計上ゆとり寸法を設けている足趾部2) に打いて接触圧が低くなったと考えられる。また，遊脚 期中の接触圧が静止立位時に比べて低い值を示した理由 として，足の形状と靴の形状との差が関係していると考 えられる。表3は足部寸法計測の結果から，JIS S 50371998 「靴のサイズ」15)により求めた足の計測值に対する 靴の適正サイズ拈よ゙゙ウィズの内訳を示した表である. 被験者の適正ウィズは，Eの者が4名，2Eの者が4名，3E の者が1名，4Eの者が1名であった．本研究において使 用した測定靴はウィズが4Eであるワイド設計の靴であっ たが，表3のように本研究に参加した被験者は足が細く， 適正ウィズがEや2Eであった者が多かったために，足部 側面である(2)第一趾脛側最突出点や(3)腓側中足点におい ては静止立位時に比べ接触圧が低くなったのではないか と推察できる.また，(2)第一趾脛側最突出点においては， 第一趾側角度が負の值を示した被験者が多く，第一趾が 足部の外側に向いている足部形状になっており，他の部 位よりも接触圧が大きくなり，またばらつきも大きくなつ たのではないかと考えられる.

以上のことから，(1)母趾球上面や(6)踵点といった部位 は，足甲部に打いて靴ずれが起こりやすい箇所 ${ }^{5}$ であり， 歩行中に足と靴の接触が発生していると考えられる。 こ のような部位では，歩行周期における身体の前進や荷重 の受け継ぎに重要な役割を持つ歩行相において静止立位 時に比べ，歩行動作中の足甲接触圧が増加することが示さ れた。 また，足部が地面から離れる遊脚期では足趾部や 足部側面に执いて靴との間に隙間が生じ，静止立位時に比 べ接触圧が低下する部位が多くなったことが示唆された。

\section{5. おわりに}

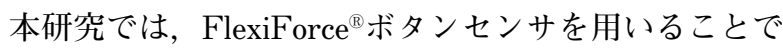


歩行中の足甲接触圧を測定した。その結果，荷重の受け 継ぎや下肢の前進に重要な役割を持つ相において，接触 圧の増加が起こりやすいということが示唆された．また， 遊脚期中においては，足部の側面や足趾部で静止立位時 に比べて接触圧が低下することが示された．このように 本研究では，フィット性の向上を目指した靴の開発の基 礎となる歩行動作中の足甲各部位における接触圧の経時 変化の特徵を提示できたと考える。

しかし, 本研究では1種類の靴のみを対象としたため, 得られた知見は類似した仕様の靴に限定される. 靴の種 類だけでなく，同じウォーキングシューズであってもアッ パー構造や素材が異なれば，異なった足甲接触圧を示す 可能性がある. また本研究の結果では接触圧のばらつき が大きく, 足の長さ, 幅, 高さなどの足部形状の個人差 が結果に影響したと考えられる。ささらに靴の種類を一つ に限定したため, 着用者の主観的なフィット性までは詳 しく追求できなかった. 今後は被験者数を増やし, 歩行 動作中の接触圧の経時変化に影響を与える足部形状や靴 の仕様を着用者の主観的なフィット性も含めながら検討 していく.

\section{利益相反}

本研究は, 九州大学と(株)ムーンスターとの共同研究に よってなされた。

\section{参考文献}

1）音成陽子, 笠原成元：靴と足のサイズに対する認識：男 女の比較, 流通科学研究, 6, 33-39, 2006

2）大塚斌：快適な靴とは, 繊維製品消費科学, 36, 673-679, 1995

3）西脇剛史：スポーツシューズの要求機能と使用素材, 繊 維学会誌, 65, 150-153, 2009

4）西脇剛史：フィット性向上を目指したスポーツシュー ズ設計, 纎維学会誌, 64, 178-183, 2008

5）西脇剛史 (監修), アシックススポーツ工学研究所 (編著) : 足と靴の科学, 日刊工業新聞社, 東京, 62-65, 2013

6）松村浩貴：ランニングシューズの購買決定要因について, 人文論集, 49, 87-99, 2014

7) Menz HB, Auhl M, et al: Evaluation of the accuracy of shoe fitting in older people using three-dimensional foot scanning, Journal of Foot and Ankle Research, 7, 3, 2014

8）高島慎吾, 仲谷政剛, 他：アッパー／足甲の接触圧分布に 基づくフィット性に関する一考察, シンポジウム : スポー ッ・アンド・ヒューマン・ダイナミクス講演論文集, A-22:1-8, 2014

9) Stolwijk NM, Koenraadt KLM, et al: Foot lengthening and shortening during gait: A parameter to investigate foot function?, Gait and Posture, 39, 773-777, 2014
10）杉本史朗, 原田一：足の動作に伴う足と靴の足長変化に 関する研究, 人間工学, 42, S412-S413, 2006

11）野川英剛, 宇治橋貞幸, 他 : ランニング・シューズのサ イズ選びに打ける心理物理的決定要因, ジョイント・シン ポジウム講演論文集, 199-202, 2003

12) Jordan C, Bartlett R: Pressure distribution and perceived comfort in casual footwear, Gait and Posture, 3, 215-220, 1995

13) Rupérez MJ, Monserrat C, et al: A study of the viability of obtaining a generic animation of the foot while walking for the virtual testing of footwear using dorsal pressures, Journal of Biomechanics, 42, 2040-2046, 2009

14) Chapman JP, Chapman LJ, et al: The measurement of foot preference, Neuropsychologia, 25, 579-584, 1987

15）日本工業規格：JIS S 5037:1998 靴のサイズ, 1998

16） Kirsten GN : 観察による歩行分析, 月城慶一, 山本澄子, 他 (訳), 医学書院, 東京, 9-15, 2005

17） Perry J, Burnfield JM : ペリー歩行分析：正常歩行と 異常歩行, 武田功, 弓岡光徳, 他 (訳), 医菌薬出版, 東京, 47-48, 2012

18) Barnett $\mathrm{CH}$ : The phases of human gait, The Lancet, 268, 617-621, 1956

19) Soames RW: Foot pressure patterns during gait, Journal of Biomedical Engineering, 7, 120-126, 1985

20) Simon SR, Paul IL, et al: Peak dynamic force in human gait, Journal of Biomechanics, 14, 817-819, 821-822, 1981

21) Whittle MW: Generation and attenuation of transient impulsive forces beneath the foot: A review, Gait and Posture, 10, 264-275, 1999

22）江原義弘, 別府政敏, 他 : 靴の踵によるエネルギー吸収 量の計算, バイオメカニズム学会誌, 26, 27-31, 2002

\section{著者情報}

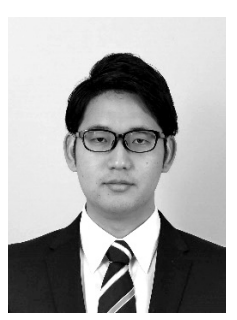

武末慎 (たけすえしん, 学生会員, 連絡著者) 2017年3月九州大学芸術工学部卒. 同大学 大学院芸術工学府芸術工学専攻デザイン人 間科学コース在学中.

連絡先：s.takesue0412@gmail.com

LOH Ping Yeap（ローピンヤップ, 正会員）

2017年3月九州大学大学院芸術工学府博士後期課程修了. 博 士 (工学)。2017年9月より, 九州大学大学院芸術工学研究院 デザイン人間科学部門助教.

村木里志（むらきさとし，正会員）

広島大学大学院生物圈科学研究科博士課程後期修了. 博士 (学 術). 県立長崎シーボルト大学 (現 長崎県立大学) を経て, 2003年より九州大学大学院芸術工学研究院デザイン人間科学 部門准教授. 2016年より教授.

古達浩史（ふるたちひろし）

1988年長崎大学工学部卒. 同年, 月星化成㑣)（現 (株ムーン スター）入社. 工場・技術・品証担当執行役員. 